\title{
Encyclopedia As A Learning Resources For Citizenship Education Courses
}

\author{
Edwin Nurdiansyah $^{1}$, Emil El Faisal $^{2}$, Sulkipani $^{3}$ \\ \{edwin@unsri.ac.id ${ }^{1}$, emil_el_faisal@fkip.unsri.ac.id ${ }^{2}$, sulkipani@fkip.unsri.ac.id ${ }^{3}$ \} \\ Universitas Sriwijaya, Jl.Palembang-Prabumulih KM 32 Ogan Ilir Sumsel, Indonesia ${ }^{123}$
}

\begin{abstract}
Learning sources are one of the supporting factors for the achievement of learning objectives, but sometimes existing learning resources do not match the characteristics of millennial students who don't like reading. So that we need learning resources that are in accordance with the millennial character but still in line with the curriculum that has been compiled. The method used is descriptive quantitative. Data were collected by distributing questionnaires to students who had attended Civics lectures. The results of the questionnaire data showed that $95 \%$ of the learning resources used by students so far were textbooks and the internet. There are $6.2 \%$ of respondents stated that their learning resources so far have not helped to understand the material being taught. and doesn't make the learning process any more interesting. From the questionnaire data, it can also be seen that all respondents like learning resources equipped with pictures and short explanations. Based on this, alternative learning sources such as encyclopedias in Civics lectures are needed in order to better help students understand the material being taught as well as make learning more interesting because it contains many pictures and shorter explanations.
\end{abstract}

Keywords: Encyclopedia, Learning Resources, Citizenship Education.

\section{Introduction}

The Citizenship Education course is one of the compulsory courses at universities in Indonesia as stipulated in Undang-undang No 12 Tahun 2012 that the higher education curriculum must contain subjects on religion, Pancasila, and Citizenship Education. and Indonesian for undergraduate and diploma programs. Without prejudice to other subjects, the government feels that the four courses have a significant role in shaping the character of young citizens as expected so that they are required in the curriculum of higher education. According to Azra [1] Civics or civic education is education that is broader in scope than democracy education and human rights education, because PKN also studies other matters such as the involvement of citizens in civil society and also the legal system, with In other words, Civics also include learning about values and morals with Pancasila as its basic foundation.

But sometimes the Civics learning process is quite boring by students, this is because the material in Civics lectures is dense and the presentation of learning resources is less attractive, even though learning resources are one of the supporting factors for achieving learning objectives. The disinterest and boredom felt by students when participating in Civics learning make the purpose of the course, namely to form the character of good citizens, will not run optimally. Therefore, civics learning resources are needed in accordance with the characteristics of students in order to be able to make Civics courses more interesting, because sometimes the 
existing learning resources are only textbooks containing long writings and not accompanied by pictures. Which learning resources are not in accordance with the characteristics of millennial students who fill learning in Higher Education.

One alternative learning resource that can be used in Civics lectures is an encyclopedia, with short explanations and attractive visualizations, it will be able to make learning material easier to understand. Encyclopedia is a book (or a series of papers bound together) which contains an explanation or discussion of a particular branch of science or field of science [2], An encyclopedia is a material that contains information along with interesting pictures or illustrations in accordance with the topics discussed [3]. So it can be concluded that an encyclopedia is a book that contains descriptions accompanied by pictures / illustrations that aim to clarify a topic discussed.

An encyclopedia in a learning process can be an enrichment material outside the main material delivered by educators to students, encyclopedias can make students understand more about the material being discussed, encyclopedias provide a more in-depth explanation [4]. Then [5] suggests that the encyclopedia has a complete and detailed explanation or discussion and is equipped with pictures so that readers can better understand and understand the information obtained.

\section{Methods}

This research uses descriptive quantitative method. The chosen research subjects were students of the Citizenship Education Program FKIP Unsri who were randomly selected (Random Sampling) based on semester levels. The data collection technique used a questionnaire and a short interview. The data analysis technique was done by calculating the questionnaire score and describing it.

\section{Result And Discussion}

The study began by giving a questionnaire to students who were randomly selected based on semester levels, a total of 80 respondents consisting of students in semester 3, semester 5 and semester 7. From questionnaire result see Figure 1,

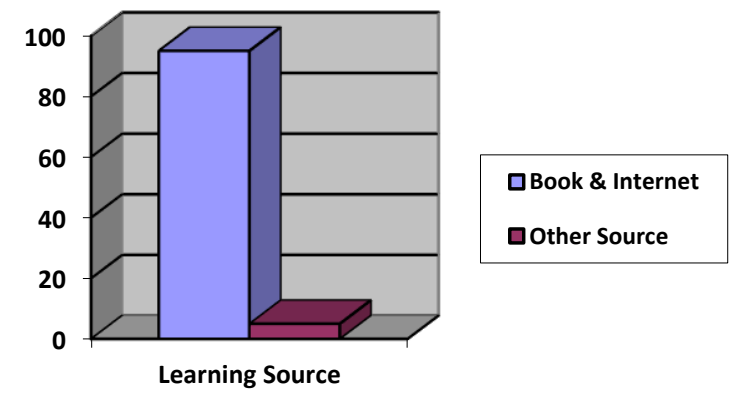

Fig. 1. Student Learning Source 
$5 \%$ of respondents answered variously such as lecturer power points, videos, journals and lecturers who teach are their learning resources. This shows that books and the internet are the biggest learning resources used by students in participating in Citizenship Education lessons.

In Aspects helped in understanding the course material and also these learning resources were able to make the learning process interesting, for a result see Figure 2.

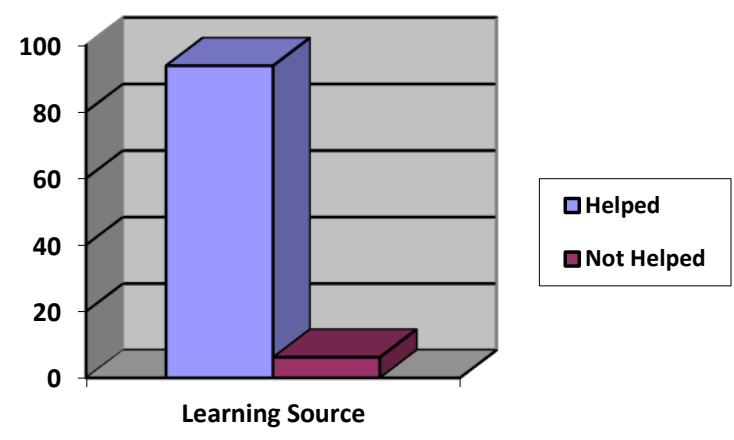

Fig. 2. Effect Learning Source

There are still $6.2 \%$ of respondents who stated that their learning resources so far have not helped in understanding the material being taught, and also these learning resources have not attracted them to participate in the learning process. In connection with this, an in-depth process was carried out through interviews with $6.2 \%$ of respondents in relation to their statements who felt their learning sources did not help in understanding unattractive learning materials and resources. The results of the interview showed that these learning resources were not attractive because they contained long texts so that students were lazy to read them, besides that, learning resources were not equipped with pictures that were able to support understanding of the material. Because of the less attractive learning resources, students are less interested in participating in the Civics learning process.

Furthermore, from the questionnaire data, it can be seen that all respondents stated that they liked learning resources equipped with images such as encyclopedias, , see Figure 3,

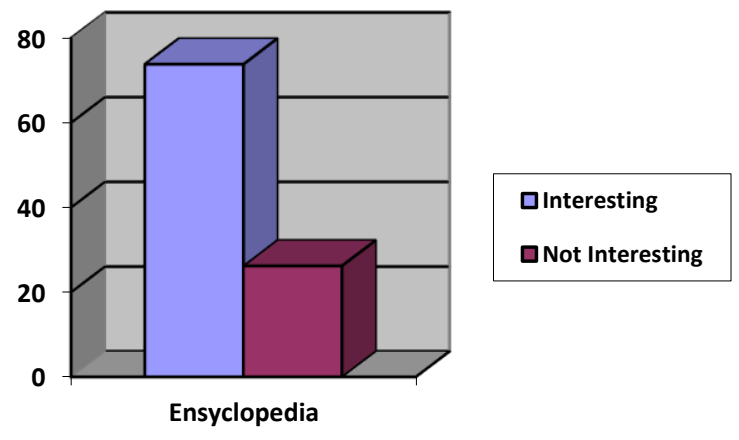

Fig. 3. An Interest in Encyclopedia 
$73.8 \%$ of respondents said encyclopedias were more interesting than ordinary text books. And $90 \%$ of respondents said encyclopedias helped in understanding the material, see Figure 4.

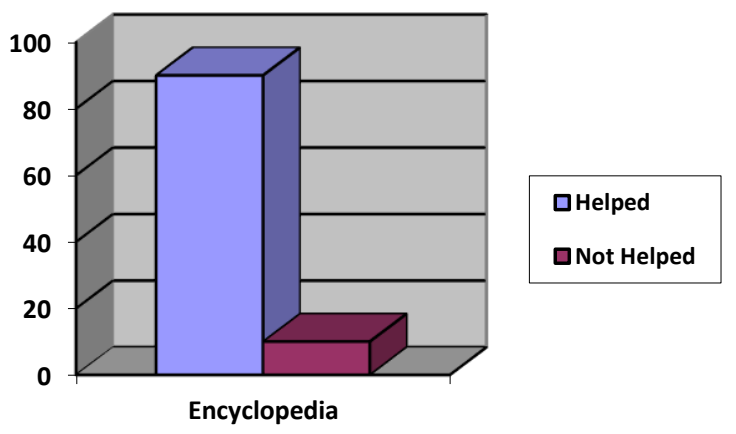

Fig.4 Usefullness an Encyclopedia

The questionnaire data illustrates that most respondents want the encyclopedia to be their learning resource when following a learning process. Suwarno [6] stated that the encyclopedia is a list of subjects accompanied by descriptions of the definition, background and bibliographic data arranged alphabetically and systematically. Furthermore, [3] suggests that an encyclopedia is a material that contains information along with interesting pictures or illustrations that match the topics discussed. Based on this definition, it can be concluded that an encyclopedia is a book containing information and is accompanied by interesting pictures according to the topic and is arranged systematically. Encyclopedia is a source of enrichment for the learning process in addition to other learning resources such as textbooks and modules. An encyclopedia is considered appropriate as a companion teaching material for teachers and students because the encyclopedia provides a brief but detailed explanation [7-10]. Ridwan and Hambali in [11] suggest that the large number of learning resources used can make it easier for students to obtain information, knowledge, experience and skills in the learning process. Given that learning resources are one of the determining factors in the success of a learning process, it becomes important to present a learning resource that is attractive to students.

Learning sources according to Dageng [8] are anything that is in the form of objects and people that can support learning so that it includes all possible sources that can be used by the teaching staff to create learning behavior. Furthermore, Sudjana [9] said that there are 2 learning resources, namely (1) designed learning resources, namely learning resources that are deliberately designed or developed as a component of an instructional system to provide focused and formal learning facilities. (2) used learning resources, namely learning resources that are not specifically designed for learning purposes and their existence can be found, applied and utilized for learning purposes. From several definitions of these learning resources, it can be concluded that learning resources are all that can support learning, whether deliberately made or not specifically designed and able to be used by the teaching staff in the learning process.

To support the achievement of Civics learning objectives, learning resources are needed that are able to facilitate the delivery of existing material to students. The right learning resources will help students understand the learning material, dense learning material such as Civics, if it is not packaged in an interesting and concise manner, it will not contribute greatly to improving students' understanding. Mulyasa [10] suggests one of the factors that causes the 
low quality of learning, among others, because learning resources have not been utilized optimally by both teachers and students.

Civics are one of the compulsory courses developed in higher education units as mandated in Law no. 12 of 2012, has a broad scope, especially in the field of governance and democracy and aims to create a civilized society. According to Mansoer [11] in essence 'Civics is the result of a synthesis between civic education, democracy education, and citizenship which is based on the Pancasila philosophy and contains Indonesian national identity and content material about state defense. . It is hoped that through Civics learning there will be individuals who have an awareness of their rights and obligations towards national development which are manifested in various active roles in every area of life.

\section{Conclusion}

It is important to present interesting learning resources in the learning process so that students' understanding of the material being taught can be further improved and able to achieve their learning objectives. Encyclopedias can be an alternative learning resource as well as enrichment in Civics lectures to help students better understand the material being taught as well as make learning more interesting because it contains many pictures and shorter explanations.

\section{References}

[1] Ubaedillah \& Rozak. 2010. Pendidikan Kewarga(negara)an (Civic Education, Pancasila, Demokrasi, HAM dan Masyarakat Madani.Jakarta: ICCE UIN Syarif Hidayatullah bekerjasama dengan Prenada Media Group.

[2] Cahyawulan, W \& Rachmawati, D. 2018. Pengembangan Ensiklopedia Pekerjaan Bidang Matematika dan Ilmu Pengetahuan Alam (MIPA) untuk Peserta Didik Kelas X di SMA Suluh Jakarta. Insight: Jurnal Bimbingan

[3] Untari, F.S. 2016. Pengembangan Ensiklopedia Keanekaragaman Capung Sungai Oyo Sebagai Sumber Belajar Biologi untuk siswa kelas X SMA/MA. Yogyakarta. UIN Sunan Kalijaga.

[4] Pratiwi, R.D. 2014. Pengembangan Ensiklopedia Bangun Datar untuk Meningkatkan Hasil Belajar siswa kelas V MI Irsyadut Tholobin Tugu Tulungagung. Malang. UIN Maulana Malik Ibrahim

[5] Prihartanta, W. 2015. . Pengembangan Ensiklopedia Umum (Nasional). Jurnal Adabiyah Vol 5 no 85 pp 1-14

[6] Nurhatmi, J. Rusdi, M. \& Kamis. 2015. Pengembangan Ensiklopedia Digital Teknologi Listrik Berbasis CTL. Jurnal Edusains Vol 4 No 1.

[7] Sulistyowati, P. Wahidiyah, D.M.N \& Setiawan, D.A. 2019. Membangun Karakter Nasionalisme Melalui Pengembangan Bahan Ajar Ensiklopedia pada Materi Tokoh-Tokoh Proklamasi. Jurnal Moral Kemasyarakatan, Vol 4 No 1 pp 32-37

[8] Bhuwana, G. Jayusma, J. \& Mutholib, A. 2017. Pengembangan Bahan Ajar berbentuk Ensiklopedia Sejarah dan Budaya Lokal Dieng pada Materi Pokok Perkembangan Kehidupan Kerajaan HinduBuddha di Indonesia di SMA N 1 Karangkobar Kabupaten Banjarnegara. Indonesian Journal of History Education. Vol 5 No 2.

[9] Ayu, Renita. 2020. Pengembangan Ensiklopedia Tumbuhan Paku Sebagai Sumber Belajar Keanekaragaman Hayati. Jurnal Biologi dan Pembelajarannya. Vol 7 No 1 pp 1-6

[10] Harahap, F. Nurliza, N. \& Nasution, E.K. 2020. Pengembangan Ensiklopedia Perbanyakan Tanaman Melalui Kultur Jaringan Sebagai Sumber Belajar Tambahan Untuk Siswa SMA.

[11]Nuraida, D \& Nisa, M U. 2017. Pengembangan Ensiklopedia Morfologi, Anatomi dan Fisiologi pada Tumbuhan Berkarakter Khusus. Proceeding Biology Education Conference Vol 14 No 1. 
[12] Supriyadi. 2015. Pemanfaatan Sumber Belajar dalam Proses Pembelajaran. Lantanida Journal Vol 3 No 2.

[13]Nur, Faizah M. 2012. Pemanfaatan Sumber Belajar dalam Pembelajaran Sains Kelas V SD pada Pokok Bahasan Mahluk Hidup dan Proses Kehidupan. Jurnal Penelitian Pendidikan Vol 13 No 1.

[14] Mulyasa. 2013. Pengembangan dan Implementasi Kurikulum 2013. Bandung: PT Remaja Rosdakarya

[15] Kaelan \& Zubaedi. 2007. Pendidikan Kewarganegaraan Untuk Perguruan Tinggi. Yogyakarta: Paradigma 